\title{
PENGARUH LONELINESS, SELF-CONTROL, DAN SELF ESTEEM TERHADAP PERILAKU CYBERBULLYING PADA MAHASISWA
}

\author{
Fadhli Anwarsyah \\ anwarsyahfadhli@gmail.com \\ mailto:afifah.fauziyyah.af@ gmail.com \\ Anggota HIMPSI Provinsi Jawa Barat
}

\author{
Gazi \\ gazi@uinjkt.ac.id \\ Fakultas Psikologi UIN Syarif \\ Hidayatullah Jakarta
}

\begin{abstract}
This research aims to determine the effect of loneliness, self-control, self-esteem against cyberbullying to UIN Syarif Hidayatullah Jakarta student. Researchers used quantitative approach with multiple regression analysis techniques. Population and sample of this research was a UIN Syarif Hidayatullah Jakarta student. The sampling used non-probability technique that involved 261 students. The measuring instrument was adapted from a scale of cyberbullying as a theory Williard, UCLA Loneliness Scale (UCLA-LS), a measuring instrument was adapted from the scale of selfcontrol as a theory Averill, The Rosenberg Self-esteem Scale. The results of this research showed that loneliness of self-control and self-esteem significantly affect cyberbullying with contribution $23 \%$. There are four variables that significantly affect the cyberbullying that trait loneliness, depression, loneliness, cognitive control, and decisional control. While social desirability variable loneliness, behavioral control and self-esteem were not significant.
\end{abstract}

Keyword : self-control, self-esteem, cyberbullying

\begin{abstract}
Abstrak
Tujuan penelitian ini untuk mengetahui pengaruh loneliness, self-control, self-esteem terhadap cyberbullying kepada mahasiswa UIN Syarif Hidayatullah Jakarta. Peneliti menggunakan pendekatan kuantitatif dengan teknik analisis regresi berganda. Populasi dan sampel penelitian ini adalah mahasiswa UIN Syarif Hidayatullah Jakarta. Pengambilan sampel menggunakan teknik non probability yang melibatkan 261 mahasiswa. Alat ukur dalam penelitian ini diadaptasi dari skala cyberbullying yang dikembangkan oleh Williard, UCLA Loneliness Scale (UCLA-LS), alat ukur diadaptasi dari skala self-control sebagai teori Averill, The Rosenberg Self-esteem Scale. Hasil penelitian ini menunjukkan bahwa loneliness, self-control dan self-esteem secara signifikan mempengaruhi cyberbullying dengan kontribusi $23 \%$. Ada empat variabel yang secara signifikan mempengaruhi cyberbullying yang sifatnya kesepian, depresi, kesepian, kontrol kognitif, dan kontrol keputusan. Sedangkan variabel kepuasan sosial kesepian, kontrol perilaku dan harga diri tidak signifikan.
\end{abstract}

Kata kunci: $\quad$ kontrol diri, harga diri, cyberbullying

Diterima: 05 Juli 2017 Direvisi: 10 Agustus 2017 Disetujui: 21 September 2017 


\section{PENDAHULUAN}

Berdasarkan data webershandwick untuk wilayah Indonesia, ada sekitar 65 juta pengguna Facebook aktif. Melihat dari analisis lain yang ditampilkan oleh situs Social Bakers, pengguna Facebook di Indonesia didominasi oleh mereka-mereka yang berumur antara 18-24 tahun di posisi pertama dan 25-34 tahun di urutan kedua. Data pengguna berusia muda tersebut juga hampir sama seperti data hasil survei yang pernah dilakukan oleh Asosiasi Penyelenggara Jasa Internet Indonesia (APJII) pada tahun 2012 lalu. Dalam hasil survei tersebut terungkap bahwa pengguna internet di Indonesia didominasi oleh pengguna berusia dengan rentang usia antara 12-34 tahun (merdeka.com).

Perkembangan media online dan gadget memang memberikan dampak positif dan negatif terhadap penggunanya. Kasus tentang bullying sudah sering terjadi di dalam kehidupan sehari-hari dan sudah berlangsung kurang lebih dari tiga puluh tahun lalu. Menurut Olweus (dalam Aoyama, 2010). Bullying merupakan perilaku agresif yang di tandai dengan tindakan berulang. Biasanya bullying melibatkan tindakkan melecehkan dan mengancam seseorang secara verbal, mengejek, menyebarkan rumor, menghasut, mnegucilkan, menakut-nakuti (intimidasi), atau menyerang secara fisik (mendorong, menampar, atau memukul). Metode lain yang umum dilakukan adalah dengan posting informasi memalukan atau memalukan tentang seseorang dalam forum publik online. Oleh karena itu, Cyberbullying melibatkan pelecehan atau penganiayaan yang dilakukan oleh pelaku terhadap korban yang jauh secara fisik. Meskipun demikian, cyberbullying dapat merusak emosional dan psikis korban (Hinduja \& Patchin, 2010).

Dampak dari cyberbullying untuk para korban tidak berhenti sampai pada tahap depresi saja, melainkan sudah sampai pada tindakan yang lebih ekstrim, yaitu bunuh diri. Hasil penelitian yang dilakukan oleh (Hinduja \& Patchin,2010). mengungkapkan fakta bahwa meskipun tingkat bunuh diri di AS menurun 28,5 \% pada tahun-tahun terakhir, namun ada tren pertumbuhan tingkat bunuh diri pada anak dan remaja usia 10 sampai 19 tahun. Salah satu faktor yang dikaitkan dengan munculnya ide untuk bunuh diri adalah pengalaman bullying. Bukti keterkaitan dini dikuatkan dengan hasil penelitian yang menunjukkan bagaimana pengalaman dipermalukan oleh sesama teman (kebanyakan sebagai target tetapi juga sebagai pelaku) berkontribusi pada munculnya depresi, penurunan kepercayaan diri, putusnya harapan dan perasaan kesepian yang kesemuanya itu menjadi pemicu munculnya pemikiran dan perilaku untuk bunuh diri. Dari hasil penelitian yang melibatkan 2000 anak usia remaja di beberapa distrik di AS, 20\% responden dilaporkan telah memikirkan secara serius untuk bunuh diri $(19,7 \%$ wanita, 20,9\% laki-laki), sementara 19\% dilaporkan telah melakukan bunuh diri (17,9\% wanita, 20,2\% laki-laki). Hal lain yang bisa disoroti dari hasil penelitian tersebut adalah semua bentuk bullying secara signifikan berkaitan dengan peningkatan munculnya ide untuk bunuh diri dan korban cyberbullying yang mencoba untuk melakukan bunuh diri hampir dua kali lebih banyak jumlahnya dibandingkan dengan remaja yang tidak mengalami cyberbullying.

Dari beberapa kajian literatur yang telah penulis lakukan sebelumnya, penulis menemukan beberapa faktor yang diduga dapat menyebabkan munculnya perilaku cyberbullying pada remaja. Salah satu faktor yang perlu diperhatikan 
adalah loneliness. Studi yang dilakukan oleh Caplan (2003) menunjukkan bahwa depresi dan loneliness merupakan prediktor signifikan untuk kecenderungan pada interaksi sosial on-line, di mana loneliness memainkan peran yang lebih signifikan dibanding depresi dalam pengembangan penggunaan internet bermasalah.

Selanjutnya, Moody (2001) menyatakan bahwa terdapat hubungan antara loneliness dan penggunaan perangkat teknologi seperti ponsel dan komputer. Dengan demikian, menjadi wajar untuk mencari korelasi antara penggunaan teknologi yang tersebar luas di kalangan remaja, dan loneliness. Ini mengarah pada gagasan bahwa para remaja menggunakan teknologi informasi untuk memuaskan rasa loneliness dengan berkomunikasi dengan orang lain. Dalam penelitian yang dilakukan oleh Sahin et.al (2012), ditemukan korelasi antara cybervictims dan loneliness. Selain itu, didapati juga hubungan yang signifikan antara cyberbullying dan loneliness.

Hasil penelitian Denson, DeWall, dan Finkel, (2012) yang menyatakan bahwa kegagalan self-control dapat memberikan kontribusi untuk tindakkan yang paling agresif yang menyertakan kekerasan. Ketika agresi mendesak menjadi aktif, self-control dapat membantu seseorang mengabaikan keinginan untuk berperilaku agresif, dan akan membantu seseorang merespon sesuai dengan standar pribadi atau standar sosial yang dapat menekan perilaku agresif tersebut. Masih sedikit studi yang mengaitkan self-control yang rendah terhadap pelaku dan korban bullying, meskipun fakta bahwa self-control yang rendah telah diidentifikasi sebagai prediktor yang penting dari perilaku penyimpangan dan kejahatan dalam studi empiris yang telah ada (Gottfredson \& Hirschi, 1990). Penelitian sebelumnya juga telah menunujukan bahwa secara langsung maupun tidak langsung rendahnya self-control mempengaruhi perilaku pelaku maupun korban dalam cyberbullying (Vazsonyi, Machackova, Sevcikova et al., 2012).

Penelitian Holt, Bossler dan May (2012) tentang tindakan cybercrime dan kenakalan remaja, menemukan hasil bahwa pelaku cybercrime dan kenakalan remaja di pengaruhi oleh rendahnya self-control dan kelompok teman dengan perilaku yang menyimpang. Rendahnya self-control tidak hanya menentukan perilaku kriminal, tetapi juga menentukan perkembangan ikatan sosial yang terjadi, self-control yang rendah dapat menggangu ikatan sosial seseorang (Wright, Caspi, Moffit, \& Silva, 1999). Dari hasil penelitiannya, Chapple, Tyler, Bersani (2005) menyimpulkan bahwa self-control yang rendah menyebabkan penolakan dari rekan sesama (peer rejection), hubungan dengan rekan atau kelompok yang menyimpang (deviant peer) dan kenakalan (delinquency). Dari literature sebelumnya menunjukan bahwa pengalaman dengan cyberbullying memiliki efek negatif pada perkembangan remaja. Salah satunya adalah self-esteem seseorang. Beberapa penelitian menyebutkan rendahnya self-esteem di temukan pada korban cyberbullying bukan pada pelaku cyberbullying (Salmivalli, Kaukiainen, Kaistaniemi, \& Lagerspetz, 1999). Sedangkan penelitian lainnya menyebutkan baik pelaku ataupun korban cyberbullying sama-sama memiliki self-esteem yang rendah dibandingkan individu yang tidak pernah mengalami cyberbullying (Patchin \& Hinduja, 2010; Fong-Ching et al, 2013). Dari beberapa hasil penelitian tenang self-esteem tersebut menjadi menarik untuk di teliti pada penelitian ini untuk lebih melihat keadaan self-esteem pada pelaku cyberbullying. 


\section{KAJIAN TEORI}

\section{Cyberbullying}

Cyberbullying adalah perlakuan kasar yang dilakukan oleh seseorang atau sekelompok orang, menggunakan bantuan alat elektronik yang dilakukan berulang dan terus menerus pada seorang target yang kesulitan membela diri (Smith, Mahdavi, Cravalho, fisher, Russell, \& Tippet, 2008). Sedangkan Hinduja \& Patchin (2007) mendefinisikannya sebagai bahaya yang disengaja dan berulang melalui media elektronik. Menurut Li (2010) cyberbullying adalah perilaku bullying yang dilakukan melalui alat komukiasi seperti e-mail, telepon selular, internet messaging atau jaringan worldwide. Sedangkan Williard (2007) mendefinisikan sebagai perilaku kejam kepada orang lain dengan mengirim hal berbahaya atau terlibat dalam bentuk lainnya dengan media internet atau teknologi digital.

\section{Loneliness}

Menurut Peplau dan Perlman (1982), loneliness adalah pengalaman yang tidak menyenangkan yang terjadi ketika hubungan sosial seseorang menurun secara kualitas maupun kuantitas. Definsi tersebut memberikan tiga elemen penting tentang bagaimana para peneliti melihat loneliness. Pertama, loneliness dihasilkan dari kurangnya hubungan sosial seseorang berkurang. Loneliness didefinisikan sebagai perasaan kehilangan dan ketidakpuasan yang dihasilkan oleh ketidaksesuaian antara jenis hubungan sosial yang di inginkan dan jenis hubungan sosial yang sudah dimiliki. Terkadang, loneliness merupakan hasil dari pergeseran kebutuhan sosial individu bukan dari perubahan tingkat kontak sosialnya. Kedua, loneliness merupakan pengalaman subjektif, yang mana tidak bisa diukur dengan observasi sederhana. Ketiga, loneliness merupakan pengalaman yang tidak menyenangkan (Peplau \& Perlman, 1982). Russell (1978) mengatakan bahwa loneliness merupakan pengalaman emosional yang tidak menyenangkan, yang terkait dengan perasaan kekosongan, kecanggungan, dan kebosanan, seseorang yang kesepian sering merasa depresi, tidak bahagia, kurang puas dengan hubungan sosial, dan merasa kurang berpenampilan menarik dari pada orang lain.

\section{Self-control}

Aktivitas pengendalian tingkah laku, yaitu melakukan pertimbanganpertimbangan terlebih dahulu sebelum memutuskan sesuatu untuk bertindak (Averill, 1973). Individu mengerahkan kontrol atas perilaku mereka sendiri dalam perbuatan sehari-hari seperti memilih sebuah perbuatan, tidak melakukan sesuatu yang berlebihan, mengikuti beberapa kegiatan untuk mempertahankan atau memulihkan kesehatan, dan bertindak dengan cara-cara yang tampaknya melanggar kepentingan diri sendiri. Namun, seorang individu mengendalikan perilakunya sendiri dengan menggunakan teknik yang serupa dengan yang akan digunakan untuk mengontrol perilaku orang lain, yaitu dengan mengubah anteseden dan sebagai akibat kondisi mengendalikan perilaku (Skinner, 1953). 
Calhoun dan Acocella (1990) mendefinisikan Self-control sebagai pengaturan proses-proses fisik, psikologis, dan perilaku seseorang dengan kata lain serangkaian proses yang membentuk dirinya sendiri. Self-control dapat diartikan sebagai suatu aktivitas pengendalian tingkah laku, pengendalian tingkah laku mengandung makna yaitu melakukan pertimbangan-pertimbangan terlebih dahulu sebelum memutuskan sesuatu untuk bertindak. Semakin intens pengendalian tingkah laku, semakin tinggi pula seseorang.

\section{Self-esteem}

Menurut Rosenberg (dalam Hinduja \& Patchin, 2010), self-esteem adalah sikap individual baik positif atau negatif terhadap dirinya sebagai suatu totalitas. Mruk (2006) menjelaskan bahwa rosberg telah menjelaskan cara lain dalam mendifinisikan selfesteem adalah suatu rangkaian sikap individu tentang apa yang dipikirkan mengenai persepsi perasaan, yaitu perasaan tentang "keberhargaan" dirinya. Sedangkan menurut coopersmith (dalam Heatherton \& Wyland, 2003) menjelaskan self-esteem sebuah penilaian pribadi terhadap keberhargaan dirinya yang diekspresikan dalam sikap yang berpegang teguh pada prinsip pribadi. Selfesteem merupakan sikap penerimaan atau penolakan yang mengindikasikan tingkat kepercayaan terhadap dirinya akan kapasitas, signifikansi, dan kesuksesan, menurut Powell, Newgent, dan Le (2006) juga berpendapat bahwa self-esteem adalah penilaian dan merasakan mengenai diri individu itu sendiri.

\section{METODE PENELITIAN}

\section{Populasi, sampel dan teknik pengambilan sampel}

Penelitian ini menggunakan pendekatan kuantitatif dengan analisi regresi berganda. Populasi dalam penelitian ini yaitu mahasiswa UIN Syarif Hidayatullah Jakarta angkatan 2016 dengan populasi 5.400 orang (pusat informasi UIN Jakarta, 2016).

Dalam hal ini Peneliti menyebarkan 200 angket kuisioner ke 11 fakultas secara acak namun angket yang di kembalikan 115 dan peneliti juga menyebar angket kuisioner secara online hasilnya ada 146, sehingga total keseluruhan angket yang di peroleh sebanyak 261 angket kuisoner yang di isi oleh mahasiswa UIN Syarif Hidayatullah Jakarta, adapun karakteristik yang di ambil untuk sampel ini adalah mahasiswa baru tingkat strata satu UIN Syarif Hidayatullah Jakarta. Teknik pengambilan sampel yang digunakan dalam penelitian ini adalah teknik non probability sampling. Non probability sampling adalah teknik pengambilan sampel yang tidak memberikan peluang atau kesempatan yang sama bagi setiap unsur atau angota populasi untuk dipilih menjadi sampel. Jenis teknik yang dipergunakan yakni convenience sampling, dimana sampel penelitian ditemukan secara kebetulan berdasarkan alasan kemudahan. 
Tabel 4.1

Gambaran umum subjek penelitian

\begin{tabular}{|c|c|c|c|}
\hline & Karakteristik sampel & Frekuensi & Persentase \\
\hline \multirow[t]{12}{*}{ Fakultas } & Fakultas Ilmu Tarbiyah \& Keguruan & 31 & $12 \%$ \\
\hline & Fakultas Adab \& Humaniora & 33 & $13 \%$ \\
\hline & Fakultas Syariah \& Hukum & 30 & $11.6 \%$ \\
\hline & Fakultas Ushuluddin \& Filsafat & 16 & $6.1 \%$ \\
\hline & Fakultas Dakwah \& Komunikasi & 32 & $12.3 \%$ \\
\hline & Fakultas Sains \& Teknologi & 21 & $8.2 \%$ \\
\hline & Fakultas Ekonomi \& Bisnis & 19 & $7.3 \%$ \\
\hline & Fakultas Dirasat Islamiyah & 12 & $5 \%$ \\
\hline & Fakultas Psikologi & 33 & $13 \%$ \\
\hline & FakultasIlmuSosial\&Ilmu & 15 & $6 \%$ \\
\hline & Pemerintahan & & \\
\hline & Fakultas Kedokteran \& Ilmu Kesehatan & 14 & $5.5 \%$ \\
\hline \multirow{2}{*}{$\begin{array}{l}\text { Jenis } \\
\text { Kelamin }\end{array}$} & Laki-laki & 96 & $36.8 \%$ \\
\hline & Perempuan & 165 & $63.2 \%$ \\
\hline \multirow[t]{4}{*}{ Usia } & $<18$ tahun & 13 & $5 \%$ \\
\hline & 18 tahun & 194 & $74.3 \%$ \\
\hline & 19 tahun & 51 & $19.5 \%$ \\
\hline & $>19$ tahun & 3 & $1.2 \%$ \\
\hline
\end{tabular}

\section{Instrumen Penelitian}

Instrument pengumpulan data yang digunakan, peneliti membuat sendiri tentang perilaku Cyberbullying yang mengacu pada aktivitas cyberbullying pada teori Williard (2007). Alat ukur terdiri dari 22 item yaitu 19 item favorable dan 3 item unfavorable. Peneliti menggunakan alat ukur UCLA Loneliness Scale ( UCLA LS) versi ketiga di kembangkan oleh Rusell (1996) yang telah diadaptasi dan disesuaikan dengan kaidah bahasa Indonesia. Kuesioner berisi 20 item yang terdiri dari tiga sub skala yaitu trait loneliness, social desirability lonleliness.

Alat ukur yang digunakan untuk variabel kontrol diri dalam penelitian ini yaitu menggunakan alat ukur yang berdasarkan atas konsep Averill (1973). Skala ini disusun berdasarkan indikator tertentu yang terdapat pada aspek-aspek kontrol diri sesuai dengan konsep Averill (1973), yaitu : 1. Behavioral control, 2. Cognitive control, 3. Decisional control.

Peneliti menggunakan alat ukur yang di kembangkan oleh Rosenberg. Peneliti mengadaptasi terlebih dahulu alat ukur The Rosenberg Self-esteem Scale dalam penelitian cyberbullying oleh hinduja \& patchin (2010). Semua alat ukur di uji validitas dengan CFA (Confirmatory Factor Analysis) dengan menggunakan 3 kriteria untuk item yang valid yaitu muatan factor tidak boleh negative, t-value $>$ 1.96, dan korelasi residual tidak lebih dari tiga. 


\section{HASIL PENELITIAN}

\section{Besaran Muatan Independent Variable terhadap Dependent Variable}

Hasil penelitian ini memiliki dapat dilihat bahwa nilai $\mathrm{R}^{2}$ sebesar 0.230 atau $23.0 \%$ artinya sumbangan varians dari cyberbullying yang dijelaskan oleh loneliness (trait loneliness, social desirability loneliness dan depression loneliness), self control (behavioral control, cognitive control dan decisional control) dan self esteem adalah sebesar $23.0 \%$ sedangkan $77.0 \%$ sisanya dipengaruhi oleh variabel lain diluar penelitian. Berikut tabel R Square:

\section{Tabel 4.5}

$R$ square

\begin{tabular}{cccccc}
\hline & & $\mathrm{R}$ & Adjusted & & \\
Model & $\mathrm{R}$ & Square & $\mathrm{R}$ Square & Std. Error of the Estimate & \\
\hline 1 & $.480^{\mathrm{a}}$ & .230 & .209 & & 8.63170 \\
\hline
\end{tabular}

Selanjutnya, besaran koefisien masing-masing IV dijelaskan dalam tabel berikut ini :

Tabel 4.7

\section{Coefficients}

\begin{tabular}{|c|c|c|c|c|c|}
\hline \multicolumn{6}{|c|}{ Coefficients $^{\mathrm{a}}$} \\
\hline \multirow{3}{*}{ Model } & \multirow{2}{*}{\multicolumn{2}{|c|}{$\begin{array}{c}\text { Unstandardized } \\
\text { Coefficients }\end{array}$}} & \multirow{2}{*}{\multicolumn{2}{|c|}{$\begin{array}{c}\text { Standardized } \\
\text { Coefficients }\end{array}$}} & \multirow{3}{*}{ Sig. } \\
\hline & & & & & \\
\hline & B & Std. Error & Beta & $\mathrm{T}$ & \\
\hline (Constant) & 65.133 & 11.826 & & 5.508 & .000 \\
\hline Trait loneliness & -.187 & .093 & -.168 & -2.008 & .046 \\
\hline Social desirability loneliness & -.056 & .085 & -.047 & -.655 & .513 \\
\hline Depression loneliness & .345 & .098 & .285 & 3.523 & .001 \\
\hline Behavioral control & .001 & .066 & .001 & .017 & .987 \\
\hline Cognitive control & -.204 & .075 & -.174 & -2.734 & .007 \\
\hline Decisional control & -.234 & .067 & -.209 & -3.512 & .001 \\
\hline Self Esteem & .032 & .073 & .030 & .436 & .663 \\
\hline
\end{tabular}

a. Dependent Variable: cyberbullying

Dari tabel 4.7, untuk melihat signifikan atau tidaknya koefisien regresi yang dihasilkan, kita cukup melihat sig pada kolom paling kanan (kolom keenam), jika $\mathrm{p}<0.05$, maka koefisien regresi yang dihasilkan, signifikan pengaruhnya terhadap cyberbullying dan sebaliknya. Dari hasil di atas trait loneliness, depression loneliness, cognitive control dan decision control memiliki koefisien nilai yang signifikan, sedangkan sisanya tidak. Hal ini berarti dari delapan hipotesis hanya terdapat empat yang signifikan 


\section{Proporsi varian}

1. Trait loneliness memberi sumbangan R2 change terhadap cyberbullying 0.120 atau $12 \%$ dengan nilai sig.F change $=0.000<0.05$. Artinya sumbangan trait loneliness signifikan terhadap cyberbullying.

2. Social desirability loneliness memberi sumbangan R2 change terhadap cyberbullying 0.000 atau $0 \%$ dengan nilai sig. $\mathrm{F}$ change $0.764>0.05$. Artinya social desirability loneliness tidak signifikan terhadap cyberbullying.

3. Depression loneliness memberi sumbangan $\mathrm{R} 2$ change terhadap cyberbullying 0.057 atau $5.7 \%$ dengan nilai sig. $\mathrm{F}$ change $=0.000<0.05$. Artinya depression loneliness signifikan terhadap cyberbullying.

4. Behavioral control memberi sumbangan R2 change terhadap cyberbullying 0.000 atau $0 \%$ dengan nilai sig. $\mathrm{F}$ change $=0.929>0.05$. Artinya behavioral control tidak signifikan terhadap cyberbullying.

5. Cognitive control memberi sumbangan R2 change terhadap cyberbullying 0.016 atau $1.6 \%$ dengan nilai sig. $\mathrm{F}$ change $=0.028>0.05$. Artinya sumbangan cognitive control tidak signifikan terhadap cyberbullying.

6. Decisional control memberi sumbangan R2 change terhadap cyberbullying 0.037 atau 3.7\% dengan nilai sig. $\mathrm{F}$ change $=0.001<0.05$. Artinya sumbangan decisional control signifikan terhadap cyberbullying.

7. Self esteem memberi sumbangan R2 change terhadap cyberbullying 0.001 atau $0.1 \%$ dengan nilai sig.F change $=0.663>0.05$. Artinya sumbangan self esteem tidak signifikan terhadap cyberbullying.

Dengan demikian dapat disimpulkan bahwa terdapat tujuh variabel independen yaitu trait loneliness, social desirability loneliness, depression loneliness, behavioral control, cognitive control, decisiónal control, dan self-esteem jika dilihat dari besarnya pertambahan $\mathrm{R}$ Square yang dihasilkan setiap kali dilakukan penambahan variabel independen (sumbangan proporsi varian yang diberikan). Dari keseluruhan varian independen tersebut yang memberikan sumbangan paling besar terhadap variabel dependen dari besarnya pertambahan $\mathrm{R}$ Square yaitu variabel decisional control dan self-esteem yang memberikan sumbangan masing-masing sebesar $23 \%$ terhadap cyberbullying.

\section{KESIMPULAN DAN SARAN}

\section{Kesimpulan}

Berdasarkan hasil analisis data penelitian pada bab sebelumnya, uji hipotesis menggunakan analisis regresi berganda, maka kesimpulan yang dapat diambil dari penelitian ini adalah: ada pengaruh yang signifikan dari loneliness (trait loneliness, social desirability loneliness dan depression loneliness), self control (behavioral control, cognitive control dan decisional control) dan self esteem terhadap cyberbullying mahasiswa UIN Syarif Hidayatullah Jakarta.

Jika dilihat dari tabel koefisien regresi pada bab empat, maka hanya ada empat variabel bebas yang memiliki nilai koefisien regresi yang signifikan, yaitu trait loneliness, depression loneliness, cognitive control, dan decisional 
control. Sementara variabel bebas lain, yaitu social desirability loneliness, behavior control, self esteem tidak signifikan dalam penelitian ini.

\section{Diskusi}

Dalam penelitian kali ini, peneliti mencoba memahami perilaku cyberbullying yang terjadi serta dampak psikologisnya, khususnya pada mahasiswa UIN Syarif Hidayatullah Jakarta melalui pengaruh faktor-faktor psikologis yang timbul dari internal individu maupun faktor eksternal yang mempengaruhi psikologis. Hasil penelitian menunjukkan bahwa ada pengaruh yang signifikan dari variabel loneliness pada dimensi trait loneliness dan depression loneliness, selanjutnya self control (cognitive control dan decisional control) terhadap perilaku cyberbullying mahasiswa UIN Syarif Hidayatullah Jakarta.

Kemudian pada variabel loneliness terdapat dua dimensi yang mempunyai pengaruh signifikan terhadap perilaku cyberbullying. Pertama adalah trait loneliness yang memiliki pengaruh negative dan signifikan, maka semakin rendah trait loneliness, semakin tinggi perilaku cyberbullying. Sejalan dengan penelitian yang di lakukan oleh (Panda, 2016) trait loneliness menjadi variabel yang signifikan karena variabel ini mewakili loneliness pada tingkat trait yang artinya sisi psikologis individu yang mengalami kesepian sudah sampai pada tahapan dimana hal itu sudah menetap, hal ini di buktikan oleh hasil penelitiannya yang menyatakan bahwa seseorang yang merasa kesepian akan merasakan kesedihan yang mendalam, dan hal-hal yang di rasakan hanya hal yang buruk pada dirinya sendiri, sehingga akan sangat sulit bagi seseorang yang memiliki kecenderungan tinggi pada trait loneliness untuk melakukan cyberbullying. Dimana pada penelitian ini di temukan bahwa semakin tinggi trait loneliness maka semakin rendah cyberbullying. Dan juga sebaliknya.

Pada dimensi kedua pada variabel loneliness yaitu dimensi depresion loneliness yang memiliki pengaruh positive dan signifikan, maka semakin tinggi depressión loneliness, semakin tinggi pula perilaku cyberbullying. Menurut Nayyar dan Singh, (2011) keterkaitan yang erat antara loneliness dan juga dimensi penting dari kepribadian pada dewasa muda patut untuk di investigasi dimana loneliness pada tahapan yang lebih tinggi sudah terkait terhadap depresi yang sifatnya klinis. Dimana pada penelitian ini di gambarkan pada dimensi depression loneliness, yang di temukan memberi pengaruh signifikan dengan arah yang positif, tentunya temuan ini berbeda dengan dimensi lain seperti trait loneliness karena depression yang sifatnya klinis menyebabkan seseorang memiliki keterampilan sosial atau berkomunikasi yang buruk (Jones, Carpenter dan Quintana, 1985). Sehingga penelitian ini membuktikan bahwa salah satu bentuk keterampilan sosial atau komunikasi yang buruk dapat di gambarkan dengan bagaimana seseorang berprilaku pada orang lainnya dalam konteks dunia maya yaitu cyberbullying.

Sementara ada dimensi lainnya dari variabel loneliness yang tidak memiliki pengaruh signifikan yakni social desirability loneliness tehadap perilaku cyberbullying. Hal ini terjadi karena dimensi ini sangat terkait erat dengan normanorma sosial sehingga hal ini tentunya tidak memberi yang signifikan padahal negatif seperti cyberbullying. 
Selanjutnya pada variabel self control di dapatkan dua dimensi yang memiliki pengaruh signifikan yaitu dimensi yang pertama adalah dimensi cognitive control yang memiliki pengaruh negative dan signifikan, maka semakin rendah cognitive control, semakin tinggi perilaku cyberbullying. Berbeda dari beberapa penelitian sebelumnya yang mengukur cognitive control yang hasilnya tidak signifikan.

Sementara pada dimensi kedua yaitu dimensi decisional control yang memiliki pengaruh secara negatif dan signifikan terhadap cyberbullying. Maka semakin rendah decisional control, semakin tinggi perilaku cyberbullying. Pada dimensi selanjutnya pada variabel self control yang tidak memiliki pengaruh signifikan yakni behavioral control terhadap perilaku cyberbullying yang artinya semakin rendah pengendalian respon secara langsung mempengaruhi perilaku maka semakin tinggi perilaku cyberbullying seseorang.

Selanjutnya pada variabel terakhir yaitu variabel self esteem tidak memiliki pengaruh signifikan terhadap perilaku cyberbullying. Hasil penelitian ini bertolak belakang dengan penelitian Patchin \& Hinduja (2010) yang menyatakan bahwa baik pelaku ataupun korban yang pernah mengalami cyberbullying samasama memiliki self-esteem yang rendah. Namun dalam studi di jelaskan, perubahan self-esteem selama masa remaja berkaitan dengan perstiwa-peristiwa hidup dan keadaan keluarga (dalam Santrock, 2012).

Teradapat beberapa kelemahan pada penelitian ini seperti, sedikitnya sampel yang kurang dapat merepresentasikan populasi. Lalu kurangnya screaning yang lebih spesifik dalam penggolongan seseorang sebagai pelaku cyberbullying. Menurut Williard (2007), frekuensi menentukan seseorang dapat dikatakan menjadi pelaku cyberbullying. Contohnya, pada hari yang sama pelaku bisa berulang kali mengirim pesan menyakitkan atau memalukan kepada orang lain. Selain itu, peneliti hanya menggunakan variabel pada faktor internal seseorang pelaku cyberbullying tanpa menambahkan faktor eksternal yang dapat mempengaruhi pelaku cyberbullying pada remaja.

\section{Saran}

\section{Saran teoritis}

1. Peneliti menyarankan untuk penelitian selanjutnya dapat digunakan variabel lain yang menarik untuk dijadikan variabel bebas yang bertujuan melihat pengaruhnya terhadap cyberbullying dan untuk mengetahui tentang cara meminimalisir perilaku cyberbullying di kalangan mahasiswa UIN Syarif Hidayatullah Jakarta.

2. Penelitian selanjutnya disarankan untuk lebih menggali mengenai beberapa variabel lainnya dengan melihat bagaimana pengaruh keempat aspek tersebut pada masing-masing dimensi terhadap cyberbullying.

\section{Saran praktis}

1. Untuk pihak kampus harus lebih meningkatkan lagi kegiatan-kegiatan positive yang bertujuan untuk membantu para mahasiswa yang memiliki kepribadian loneliness tersebut untuk bisa lebih berpartisipasi aktif lagi di dalam kegiatan positive tersebut. 
2. Salah satu peran penting kampus adalah memberikan pesan-pesan moral terhadap mahasiswa melalui nilai-nilai keagamaan yang mana di dalamnya dapat menjadi benteng terhadap mahasiswa dalam menjadikan pribadi yang lebih baik lagi.

3. Peran kampus sangat penting dalam memberikan pembekalan positive terhadap mahasiswa dalam bentuk kegiatan pengajaran dan pengetahuan secara masif, agar mahasiswa di kalangan UIN Syarif Hidayatullah Jakarta ini dapat meminimalisir prilaku cyberbullying.

\section{DAFTAR PUSTAKA}

Ang, R. P., Tan, K., Mansor, A. T. (2011). Normative beliefs about aggression as a mediator of narcissistic exploitativeess and cyberbullying. Journal of Interpersonal Violance, 26(13), 82-105.

Aoyama, I., Saxon, T. F., Fearon, D. (2010). Internalizing problems among cyberbullying victims and moderator effects of friendship quality. Multicultural Education \& Technology Journal, 5 (2), 92-105.

Badriyah, L. (2013). Pengaruh empati dan self-control terhadap agresivitas remaja SMA Negeri 03 kota tanggerang selatan. Skripsi. Jakarta: universitas islam negeri syarif hidayatullah.

Bossler, A. M. \& Holt, T. J. (2011). Patrol officers' perceived role in responding to cybercrime. Police Strategies \& Management. 35 (1), 165-181.

Calhoun, J. F. \& Acocella, J. R. (1990). Psychology of adjustment and human relationship. New York: McGraw-Hill,inc

Campfield, D. C. (2006). Cyberbullying and Victmization: Psychosocial characteristic of bullies, victims, and bully/victims. Dissertations, Professional Papers. Retrived from http://scholarworks.umt.edu/etd/288

Caplan, S., E. (2003) A theory of problematic internet use and psychosocial wellbeing. Communication Research, 30 (6), 625-648..

Denson, T. F., Dewall, C. N., Finkel, E. J. (2012). Self-control and Agression. Association for Psychological Science. 21 (1), 20-25.

Heirman, W. \& Walrave, M. (2012). Predicting adolescent perpetration in cyberbullying: an application of the theory of planned behavior. Psichotema, 24 (4), 614-620.

Heatherton, C. \& Wyland, L. (2003). Assessing self-esteem. Retrived 2 juni 2014 from http://www.dartmouth.edu/thlab/pubs/03 Heatherton Wyland APPch.pdf

Hinduja, S. and Patchin, J. W. (2007). Offline consequnces of online victimization: school violence and deliquence. Journal of school violence. 6 (3), 89-113.

Hoff, D.L. \& Mitchell, S.N. (2009). Cyberbullying: causes, effects, and remedies. Journal of Educational Administration. 47(5), 652-665.

Heatherton, T. D. \& Polivy, J. (1991). Development and validation of a scale for measuring state self- esteem. Journal or Personality and Social Psychology, 60(6), 895-910 
Jones, W. H., Carpenter, B. N., \& Quintana, D. (1985). Personality and interpersonal predictors of loneliness in two cultures. Journal of Personality and Social Psychology, 48, 1503-1511.

Li, K. (2010). A study of relationship between cyber-bullying and personalityof the elders at Kaoshiung, Taiwan. Diunduh pada tanggal 24 September 2016 dari http;//etd.npue.edu.tw/ ETD-db/ETD- search /view_etd? URN = etd-0720111-231019

Marden, N. E. (2010). Exposing the cyberbully. Diunduh pada tanggal 24 September 2016 dari http;//lbrary.wcsu.edu/dspace/bitstream/0/526/1/ CYBERBULLYING_THESIS_FINAL.pdf

Menesini, E., Nocentini, A., \& Palaadino, B.E. (2012). Online and offline peer led models against bullying and cyberbullying. Journal of Psychotema. 24 (4), 634-636.

Minchiton, J. (1995). Maximum self-esteem. Golden Book Center: Kuala Lumpur.

Mruk, C. J. (2006). Self-esteem research theory and practive: toward a positive psychology of self-esteem. New York: Springer Publishing Company, Inc.

Panda, S. (2016). Personality Traits And The Feeling Of Loneliness Of PostGraduate University Students. The International Journal of Indian Psychology. 3 (1), 123-126

Patchin, J. W. \& Hinduja, S. (2010). Cyberbullying and self-esteem. Journal School Health, 80 (12), 137-142

Peplau, L. A. \& Perlman, D. (1976). A Sourcebook of current theory, research and theraphy. A Wiley Interscience Publication, 259-260.

Powell, M. S., Newgent, R. A., \& Le, M. (2006). Group cinematherapy: Using metaphor to enhance adolescent self-esteem. The art in Psychoteraphy, 33, 247-253

Riebel, J., Jager, R. S., \& Fischer, U. C. (2009). Cyberbullying in Germany - an exploration of prevalence, overlapping with real life bullying and coping strategis. Psychology Science Quarterly, 5 (13), 298-314

Rubin, R. B., \& McHugh, M. P. (1987). Development of parasocial interaction relationships. Journal of Broadcasting \& Electronic Media, 31, 279-292

Russel, D., Peplau, L. A., Ferguson, M. L. (1978). Developing a measure loneliness. Journal Of Personality Assessment, 42 (3), 122-127

Russel D. W. (1996). Ucla loneliness scale (version 3): reliability,validity, and factor structure. Journal of Personality Assessment, 66 (1), 20-40

Sahin, M. (2012). The relationship between the cyberbullying/cybervictmization and loneliness among adolescents. Children and Youth Service, Review. 34, 834-837.

Skrinner, B. F. (2005) Science and human behavior. Massachusetts: B. F. Skinner Foundation.

Salmivalli, C,. Kaukiainen, A., Kaistaniemi, L., Lagerspetz, K. M. J. (1999). Self evaluated self-esteem, peer-evaluated self-esteem, and defensive egotism as predictors of adolescents' participation in bullying situations. Personality and Social Psychology Bulletin. 25 (10) 1268-1278. 
Setianingrum, A. (2015) Pengaruh empati, self-control, dan self-esteem terhadap perilaku cyberbullying pada siswa sman64 jakarta. Skripsi Universitas Islam Negeri Jakarta.

Smith, P. K., Mahdavi, J., Carvalho, M., Fisher, S., Rusell, S., \& Tippett, N. (2008). Cyberbullying : Its nature and imopact insecondary school pupils. Journal of Psychology and psychiatry, 49 (2), 376-385

Steinberg, L., \& Morris, A. S. (2001). Adolance development. Annu Rev Psychol, 52,83-110.

Susanto, Andi. (2013). Data terkini pengguna facebook di Indonesia. Diunduh tanggal

18 September 2016 dari https://www.merdeka.com/teknologi/data-

terkini-pengguna-facebook-di-indonesia.html

Topcu, C., \& Erdu-Barker, O. (2010). The revised cyber bullying inventory (RCBI): validity and reliability

studies. Procedia Social and Behavioral Sciences, 5, 660-664.

Trzesniewski, K.H., Donnellan, M.B, \&Robins, R.W. (2003).Stability of selfesteem across the life span. Journal of Personality and social psychology, 84 (1), 205-220

Vazsonyi, A. T., Machackova, H., Sevcikova, A. (2012). Cyberbullying in context: direct and indirect effects by low self-control across 25 european countries. European Journal Of Developmental Psychology. 9(2), 210-227.

Williard, N. (2007).Educator's guide to cyberbullying and cyberthreats. Diunduh pada tanggal 11 Agustus 2015 dari http://csriu.org/

Wright, B. R. E., Caspl, A., Moffitt, T. E., Silva, P. A. (1999). Low self-control, social bonds, and crime: social causation, social selection, or both? Criminolgy. 37 (3), 479.

. (2013). Kominfo: pengguna internet di Indonesia 63 juta. Diunduh tanggal 18september2016darihttps://kominfo.go.id/index.php/content/detail/34

$15 /$ Kominfo $\% 3 \mathrm{~A}+$ Pengguna+Internet+di+Indonesia $+63+$ Juta+Orang/ $\underline{0 / \text { berita satker }}$ . (2013). Hannah bunuh diri akibat dibully dan diminta mati di dunia maya.

Diunduh tanggal 19 september 2016 dari

http://global.liputan6.com/read/659896/hannah-bunuh-diri-akibat-dibullydan-diminta-mati-di-dunia-maya 